УДК 615.33.065:616-06-055.2

Короткі повідомлення

DOI 10.11603/1811-2471.2020.v.i2.11348

\title{
AN ANTIBIOTIC DRUG-INDUCED ALLERGIC REACTION IN A PATIENT WITH MULTIPLE COMORBIDITIES. CLINICAL CASE
}

\author{
๑G. E. Kuodza, P. O. Kolesnyk
}

\section{Uzhhorod National University}

SUMMARY. Drug induced allergic reactions due to antibiotics rarely occur. Penicillin is the antibiotic class that is mostly commonly associated with drug induced allergic reactions (10\%). They are followed by quinolones (2\%) which will be discussed in this case based review. Fluoroquinolones allergic reactions can either present as an immediate reaction which requires urgent medical attention or a delayed reaction. Among the antibiotics of this class, moxifloxacin has been reported as the drug which is likely to result in occurrence of an allergic reaction. Some of the dermatologic eruptions that could manifest include maculopapular exanthema, urticarial, Steven Johnson Syndrome, fixed drug eruptions and drug rash with eosinophilia and systemic symptoms (DRESS). The diagnosis needs a thorough history and physical examination, skin test, in vitro testing and drug provocation tests. Management includes discontinuation of the provoking agent and administration of antihistamines or corticosteroids depending on the situation.

The case of the 75 year old lady who had an allergic reaction following administrations of ciprofloxacin and follow up management plan is described in the article. The case illustrates and urgent necessity of quaternary prevention in primary care to avoid harming patients while choosing the best and safe therapy.

KEY WORDS: antibiotic allergic reaction; fluoroquinolones; primary care; comorbidities; maculopapular exanthema.

Introduction. Drug induced allergic reactions due to antibiotics rarely occur. Penicillin is the antibiotic class that is mostly commonly associated with drug induced allergic reactions (10\%). They are followed by quinolones (2 \%) which will be discussed in this case based review. Fluoroquinolones allergic reactions can either present as an immediate reaction which requires urgent medical attention or a delayed reaction. Among the antibiotics of this class, moxifloxacin has been reported as the drug which is likely to result in occurrence of an allergic reaction. Some of the dermatologic eruptions that could manifest include maculopapular exanthema, urticarial, Steven Johnson Syndrome, fixed drug eruptions and drug rash with eosinophilia and systemic symptoms (DRESS). The diagnosis needs a thorough history and physical examination, skin test, in vitro testing and drug provocation tests. Management includes discontinuation of the provoking agent and administration of antihistamines or corticosteroids depending on the situation.

Case report. A 75-old year female presented to the clinic complaining of a rash. Her rash was maculopapular which was distributed on the truncal region and the back. The pink-red erythematous lesions were non-pruritic and non-painful. She had no fever, no blisters or pustules. The rash started 24 hours after oral administration of ciprofloxacin $500 \mathrm{mg}$ which had been prescribed for a possible urinary tract infection. Her urinary tract infection was questionable at this stage as she had cervical polyps and she had an episode of haematuria a few days back. In relation to her haematuria she admitted to painful burning urination which also started a few days back but she denied any fever chill or nausea in relation to this episode. On assessment of her past medical history it revealed that she had arterial hypertension which had been diagnosed in 1995 but had been uncontrolled of late. She also suffers from sub-compensated type 2 diabetes for the past 15 years. Due to her diabetes she has diabetic polyneuropathy, diabetic foot and peripheral artery disease. She had previously been admitted in hospital due to an acute exacerbation of bronchial asthma during her childhood. However at this stage it was in remission. 10 years back she was diagnosed with cervical polyps. For the past 8 years she has been suffering from ischemic heart disease and dyslipidemia. In her past surgical history she had a previous hysterectomy which was performed in 2000 and an intracerebral tumour which was operated in 2010 this was later complicated by osteomyelitis of the frontal bone which resulted in resection of the bone the same year. Following these procedures she had an allergic reaction to ceftriaxone. Her drug history has the following drugs Amlodipine $5 \mathrm{mg} O D$, Nebivolol 2,5 mg OD in the morning, Azilsartan $40 \mathrm{mg}$ OD, Chlortalidone $12.5 \mathrm{mg} O D$, rosuvastatin $10 \mathrm{mg} O D$, Insulin (Khumodar) $22+22$ once daily, metformin $1000 \mathrm{mg}$ BID, Clopidogrel $75 \mathrm{mg}$ OD.

The patient reported that she did not abuse any illicit drugs. She also mentioned that she neither smokes nor drinks alcohol.

Physical examination revealed a well-nourished lady who was in no distress. She was pale, was afebrile, conscious and well-orientated to place and time. Her BMI was $32 \mathrm{~kg} / \mathrm{m}^{2}$. The pulse rate was regular 69 per minute, blood pressure $165 / 85 \mathrm{~mm} \mathrm{Hg}$, and respiratory rate 18 per minute. Physical examination of the 
Огляди літератури, оригінальні дослідження, погляд на проблему, випадок з практики, короткі повідомлення

rash revealed a bilateral symmetrical erythematous maculopapular rash that was evenly distributed on the back and the trunk. Her skin was dry and she had a purpuric lesion on the extensor surface of her hand. However there was no mucosal involvement of the rash. All other systems were normal.

Lab results

HbA1c 7.9 \% measured 3 months ago (normal range: $<5.9 \%$; target: $<7 \%$ )

Urine analysis - Epithelial cells 4-6 Leucocytes 20-22 erythrocytes 1-5

CBC WBC $8.7 * 10^{9 / L}$ RBC 3,58* 1012/L Haemoglobin $99 \mathrm{~g} / \mathrm{L}$ MCV 89.8 fL MCH 27.6 pg platelets 126 *10 $9 / \mathrm{L}$

Lipid profile - total cholesterol-5,3 mmol/L LDL3,2 mmol/L HDL-0,9 mmmol/L

Her liver enzymes AST 81,0U/L ALT 56,0U/L Uric acid 386,5 micromol/L

Creatinine 10,3 micromol/L

ECG taken in January showed normal sinus rhythm, with left ventricular hypertrophy, discordant changes ST segment depression in V4-V6 and ST-segment elevation in V1-V3, as well as left axis deviation.

Assessment

Drug Induced allergic reaction

Possible urinary tract infection

Cervical polyps, status unknown

Uncontrolled stage 2 hypertension despite antihypertensive

Dyslipidemia, elevated LDL cholesterol despite statin therapy

Sub-compensated type 2 diabetes despite therapy

Anaemia of Chronic Disease

Thrombocytopenia of unknown aetiology

Ischemic heart disease, stable

Bronchial Asthma, stable

Obesity, stable

Post-operative frontal craniotomy, stable

Cervical polyps, status unknown

Low socio-economic status with unstable income from caregivers

Discussion. To summarize we have a 75 year old lady with comorbidities who presented with a drug induced allergic reaction following administration of ciprofloxacin. This patient was challenging for us because this patient was very ill, meaning that all the medication she was taking was necessary for her survival. We managed to rule out other possible causes related to a maculopapular rash and concluded it was a drug eruption due to antibiotic allergy [1][2][3]. According to the management of drug eruptions the main therapy involves discontinuing the offending agent and then providing the patient with either corticosteroids or antihistamine [4]. The corticosteroids can be given as systemic corticosteroids or topical corticosteroids. Upon thoughtful consideration it was better not to use corticosteroids in this case, this is because the glucocorticoids could potentially worsen her hypertension which was already uncontrolled at this stage. If that occurred this could lead to complications such as cerebrovascular accident which could be fatal considering her post-operative history and age. The second problem that could possibly occur was that administration of corticosteroids would result in elevation of her blood glucose which could possibly put her at risk of getting acute complications such as hyperosmolar hyperglycaemic state. Thirdly in an immunocompromised individual adding corticosteroids can only supplement a cascade of problems that could arise as a result of a weak immune system. A weakened immune system could result in worsening of her urinary tract infection and it would make her more susceptible to new infections such as SARSCoV-2. Based on this corticosteroids were definitely not the option for her hence it was best to provide her with antihistamine therapy instead. The drug of choice that was selected in this case desloratadine which is a second generation antihistamine. In addition to desloratadine she was instructed to stop the offending agent. The treatment regime $5 \mathrm{mg}$ four times daily and she was instructed to come back for follow-up [5].

In respect to her other comorbidities that management was as follow, a dose of amlodipine was increased to $10 \mathrm{mg}$ as she complained that her blood pressure mostly increased at night. Her dose of rosuvastatin was increased as well as she still had uncontrolled LDL.

\section{Outcomes}

The patient returned to the clinic a week later her rash had resolved. However her blood pressure had not reached the target, we decided to wait for 3 more weeks as the therapeutic effect would be expected in 4 weeks.

Conclusion. Although not common drug allergic reactions to antibiotics due to quinolones have been increasing and Family Doctors need to be aware of the presentations and possible complications that could possibly occur.

It is paramount for all physicians as well to be able to consider risks and benefits in every clinical scenario as that would assist in directing the choice of therapy. 
Огляди літератури, оригінальні дослідження, погляд на проблему, випадок з практики, короткі повідомлення LITERATURE

1. Update on quinolone allergy / I. Doña, E. Moreno, N. Pérez-Sánchez [et al.] // Curr. Allergy Asthma Rep. 2017. - Vol. 17 (8). - P. 56.

2. Hypersensitivity reactions to fluoroquinolones / M. Salas, E. Barrionuevo, T. D. Fernandez [et al.] // Curr. Treat. Opt. Allergy. - 2016. - No. 3. - P. 129-146. DOI: $10.1007 / \mathrm{s} 40521-016-0079-z$

3. Antibiotic allergy / K. G. Blumenthal, J. G. Peter, J. A. Trubiano, E. J. Phillips // Lancet. - 2019. - No. 393 (10167). - P. 183-198.

\title{
REFERENCES
}

1. Doña, I., Moreno, E., Pérez-Sánchez, N., Andreu, I., Hernández Fernandez de Rojas, D., \& Torres, M.J. (2017). Update on quinolone allergy. Curr. Allergy Asthma Rep., 17 (8), 56.

2. Salas, M., Barrionuevo, E., Fernandez, T.D., Ruiz, A., Andreu, I., Torres, M.J., \&Mayorga, C. (2016). Hypersensitivity reactions to fluoroquinolones. Curr. Treat. Opt. Allergy., 3, 129-146. DOI: 10.1007/s40521-016-0079-z

3. Blumenthal, K.G., Peter, J.G., Trubiano, J.A., \& Phillips, E.J. (2019). Antibiotic allergy. Lancet, 393 (10167), 183-198.

4. Blume J. Drug eruptions treatment \& management: Medical care / J. Blume, L. Ali // Retrieved June 10, 2020. - URL : https://emedicine.medscape.com/article/ 1049474- treatment

5. The EAACI/GA²LN/EDF/WAO guideline for the definition, classification, diagnosis and management of urticaria / T. Zuberbier, W. Aberer, R. Asero [et al.]. URL : //onlinelibrary.wiley.com/doi/full/10.1111/all.13397

4. Blume, J., \& Ali, L. (2020). Drug Eruptions Treatment \& Management: Medical Care. Retrieved from: https:// emedicine.medscape.com/article/1049474-treatment

5. Zuberbier, T., Aberer, W., Asero, R., Latiff, A.H.A., Baker, D., Ballmer-Weber, B., \& Maurer, M. (2018). The EAA$\mathrm{Cl} / \mathrm{GA}{ }^{2} \mathrm{LEN} / \mathrm{EDF} / \mathrm{WAO}$ guideline for the definition, classification, diagnosis and management of urticaria. Retrieved from: https://onlinelibrary.wiley.com/doi/full/10.1111/ all.13397

\section{АЛЕРГІЧНА РЕАКЦІЯ, СПРИЧИНЕНА ПРИЙОМОМ АНТИБІОТИКА, У ПАЦІЕНТКИ З ПОЛІМОРБІДНОЮ ПАТОЛОГІЄЮ. КЛІНІЧНИЙ ВИПАДОК}

\author{
Ужгородський національний університет
}

РЕзЮМЕ. Алергічні реакції, спричинені лікарськими засобами, зокрема антибіотиками, трапляються нечасто. Пеніцилін - це клас антибіотиків, який, як правило, асоціюється з алергічними реакціями, спричиненими лікарськими засобами (10 \%). Наступними за частотою алергічних реакцій $є$ фторхінолони (2 \%), що описано у статті. Алергічні реакції на фторхінолони можуть бути негайного типу, що вимагають термінової медичної допомоги, або сповільненого типу. Серед антибіотиків цього класу моксифлоксацин описаний як препарат, який, ймовірно, може спричинити виникнення алергічної реакції. Деякі дерматологічні прояви таких реакцій включають макулопапульозну екзантему, кропив'янку, синдром Стівена-Джонсона, локальну реакцію на введення медикаменту з еозинофілією та системними проявами (DRESS). Встановлення діагнозу вимагає ретельного збору анамнезу та фізикального обстеження, проведення шкірних тестів, тестування in vitro та провокаційними тестами на медикаменти. Ведення пацієнтів вимагає негайного припинення дії провокуючого агента та прийом антигістамінних препаратів або кортикостероїдів, залежно від ситуації.

У статті описано клінічний випадок 75-річної жінки, яка мала алергічну реакцію після прийому ципрофлоксацину, з характеристикою її подальшого ведення з врахуванням поліморбідної патології. Цей випадок ілюструє нагальну необхідність у дотриманні четвертинної профілактики в первинній медичній практиці з метою уникнення шкоди пацієнтам шляхом вибору найкращої і безпечної терапії.

Ключові СловА: алергічна реакція на антибіотики; фторхінолони; первинна допомога; супутні захворювання; макулопапульозна екзантема. 
Огляди літератури, оригінальні дослідження, погляд на проблему, випадок з практики, короткі повідомлення

\section{АЛЛЕРГИЧЕСКИЕ РЕАКЦИИ, ВЫЗВАННЫЕ ПРИЕМОМ АНТИБИОТИКОВ, У ПАЦИЕНТКИ С ПОЛИМОРБИДНОЙ ПАТОЛОГИЕЙ. КЛИНИЧЕСКИЙ СЛУЧАЙ}

\section{๑Дж. Э. Куодза, П. А. Колесник}

\section{Ужгородский национальный университет}

PЕЗЮмЕ. Аллергические реакции, вызванные лекарственными средствами, в частности антибиотиками, встречаются редко. Пенициллин - это класс антибиотиков, который, как правило, ассоциируется с аллергическими реакциями, вызванными лекарственными средствами (10\%). Следующие по частоте аллергических реакций фторхинолоны (2 \%), что описано в статье. Аллергические реакции на фторхинолоны могут быть немедленного типа, требующие срочной медицинской помощи, или замедленного типа. Среди антибиотиков этого класса моксифлоксацин описан как препарат, который, вероятно, может вызвать аллергическую реакцию. Некоторые дерматологические проявления таких реакций включают макулопапулезную экзантему, крапивницу, синдром Стивена-Джонсона, локальную реакцию на введение медикамента с эозинофилией и системными проявлениями (DRESS). Установление диагноза требует тщательного сбора анамнеза и физикального обследования, проведения кожных тестов, тестирования in vitro и провокационными тестами на медикаменты. Ведение пациентов требует немедленного прекращения действия провоцирующего агента и приема антигистаминных препаратов или кортикостероидов, в зависимости от ситуации.

В статье описан клинический случай 75-летней женщины, которая имела аллергическую реакцию после приема ципрофлоксацина, с характеристикой дальнейшего ее ведения с учетом полиморбидной патологии. Этот случай иллюстрирует настоятельную необходимость в соблюдении четвертичной профилактики в первичной медицинской практике во избежание вреда пациентам путем выбора лучшей и безопасной терапии.

КЛЮчЕВЫЕ СЛОВА: аллергическая реакция на антибиотики; фторхинолоны; первичная помощь; сопутствующие заболевания; макулопапулезная сыпь.

Отримано 12.05 .2020 